University of Nebraska - Lincoln

DigitalCommons@University of Nebraska - Lincoln

\title{
Vulnerability of crops and croplands in the US Northern Plains to predicted climate change
}

\author{
Brian J. Wienhold \\ USDA-ARS, Brian.Wienhold@ars.usda.gov \\ Merle F. Vigil \\ USDA-ARS, Merle.Vigil@ars.usda.gov \\ John R. Hendrickson \\ USDA-ARS, john.hendrickson@ars.usda.gov \\ Justin D. Derner \\ USDA-ARS, Justin.Derner@ars.usda.gov
}

Follow this and additional works at: https://digitalcommons.unl.edu/usdaarsfacpub

Wienhold, Brian J.; Vigil, Merle F.; Hendrickson, John R.; and Derner, Justin D., "Vulnerability of crops and croplands in the US Northern Plains to predicted climate change" (2017). Publications from USDA-ARS / UNL Faculty. 1783.

https://digitalcommons.unl.edu/usdaarsfacpub/1783

This Article is brought to you for free and open access by the U.S. Department of Agriculture: Agricultural Research Service, Lincoln, Nebraska at DigitalCommons@University of Nebraska - Lincoln. It has been accepted for inclusion in Publications from USDA-ARS / UNL Faculty by an authorized administrator of DigitalCommons@University of Nebraska - Lincoln. 


\title{
Vulnerability of crops and croplands in the US Northern Plains to predicted climate change
}

\author{
Brian J. Wienhold ${ }^{1}$ (D) Merle F. Vigil ${ }^{2}$. \\ John R. Hendrickson ${ }^{3}$ • Justin D. Derner ${ }^{4}$
}

Received: 2 December 2016 / Accepted: 3 May 2017

(C) Springer Science+Business Media Dordrecht (outside the USA) 2017

\begin{abstract}
The states of Colorado, Montana, Nebraska, North Dakota, South Dakota, and Wyoming comprise the Northern Great Plains region of the USA. The soil and water resources contained in this region have historically supported highly diverse and productive agriculture enterprises that provide a significant proportion of the food, feed, and oilseed for the nation. The region also provides ecological services that influence air, water, and soil quality along with biological diversity. Combined with livestock production and a biofuel industry, crop production forms an integrated system that can offer producers flexibility in management decisions. Projected climatic changes for this region include increasing atmospheric $\mathrm{CO}_{2}$, a longer, warmer growing season, and increased precipitation, likely received in more frequent extreme events. These changes will impact soil and water resources in the region and create opportunities and challenges for land managers. The objectives of this paper are to describe anticipated impacts of projected mid-(2050) and late-(2085) climatic changes on crop
\end{abstract}

This article is part of a Special Issue on 'Vulnerability Assessment of US Agriculture and Forests developed by the USDA Climate Hubs' edited by Jerry L. Hatfield, Rachel Steele, Beatrice van Horne, and William Gould.

Brian J. Wienhold

Brian.Wienhold@ars.usda.gov

Merle F. Vigil

Merle.Vigil@ars.usda.gov

John R. Hendrickson

John.Hendrickson@ars.usda.gov

Justin D. Derner

Justin.Derner@ars.usda.gov

1 USDA-ARS, 251 Filley Hall/Food Ind. Complex, East Campus, University of Nebraska—Lincoln, Lincoln, NE 68583-0937, USA

2 USDA-ARS, 40335 County Road GG, Akron, CO 80720, USA

3 USDA-ARS, Box 459, Mandan, ND 58554, USA

4 USDA-ARS, 8408 Hildreth Road, Cheyenne, WY 82009, USA 
production systems in the Northern Great Plains and provide adaptation strategies that should be developed to take advantage of positive and mitigate negative changes. Projected climatic changes will influence agricultural productivity directly as well as indirectly due to changes in weed pressure, insect populations, and diseases. A warmer, longer growing season will change the crops and distribution of those crops grown within the region. An increase in the number of extreme temperature events (high daytime highs or nighttime lows) will decrease crop yields due to increased plant stress during critical pollination and grain fill periods. Adaptation strategies to reduce vulnerability of soil and water resources to projected climatic changes include increasing cropping intensity, reducing tillage intensity, and use of cover crops to provide surface cover to reduce erosion potential and improve nutrient and water use efficiency. Increased use of perennial forages, crop residue, and failed crops in integrated croplivestock systems will add biological diversity and provide options for converting vegetation biomass into animal protein. Socio-economic changes will need to be incorporated into adaptation strategies planning to insure that sustaining ecosystem services and meeting desired production and conservation goals is accomplished. Education and extension services will be needed to transfer adaptive knowledge in a timely manner to producers in the field.

\section{Introduction}

The Northern Great Plains comprises the states of Colorado, Montana, Nebraska, North Dakota, South Dakota, and Wyoming. This region has a continental climate characterized by cold winters, hot summers, and highly variable precipitation. Much of the region was glaciated and soils across the region are relatively young and highly fertile. Within the region there are strong gradients in average annual precipitation and temperature with average annual temperature decreasing from south to north and average annual precipitation decreasing from east to west (Lauenroth et al. 1999). These climatic and edaphic conditions result in the region being well suited to grow a number of different crops.

The Northern Great Plains has significant surface and ground water resources. Major rivers include the Missouri and Platte. The Missouri River originates in Montana and flows through North Dakota and South Dakota. The Platte River originates in Wyoming and Colorado and flows through Nebraska. Both of these rivers are dependent on meltwater from mountain snowpack for a portion or most of their flow. There are also a number of smaller locally important rivers throughout the region. Many of the rivers in the region have reservoirs constructed to retain water for irrigation, municipal use, recreation, erosion control, and storage as well as to manage downstream flow seasonality and amount. The southern portion of the region overlies the High Plains Aquifer with other smaller ground water resources within the region. These water resources support irrigation in many areas allowing production of crops with water demands greater than that provided by precipitation and sustain production during below normal precipitation periods. As an example, Nebraska has more irrigated acres than any other state in the USA (USDA-NASS 2013). Irrigation development varies greatly throughout the region and is dependent on proximity to water resources, water quality (salinity and sodicity), and suitability of soils to support irrigation (depth to water table, internal drainage capacity) (Springer et al. 1999).

In 2015, this region represented $24.6 \%$ of the cropland area planted in the USA and produced $90 \%$ of the canola (Brassica napus L.), $84 \%$ of the sunflower (Helianthus annuus L.), $60 \%$ of the barley (Hordeum vulgare L.), $48 \%$ of the dry edible bean (Phaseolus vulgaris 
L.), $38 \%$ of the wheat (Triticum aestivum L.), $30 \%$ of the sugarbeet (Beta vulgaris L.), $22 \%$ of the corn (Zea mays L.), $22 \%$ of the hay, and $18 \%$ of the soybean (Glycine max (L.) Merr.) (USDA-NASS 2016a). The region also produces smaller amounts of a number of other crops (e.g. oats (Avena sativa L.), flax (Linum usitatissimum L), safflower (Carthamus tinctorius L.), potato (Solamum tuberosum L.), and sorghum (Sorghum bicolor (L.) Moench)). Crops harvested in 2015 had a value of \$27.1 billion (USDA-NASS 2016b). Sustaining production in this region is essential to meeting future food, feed, fiber, and fuel demands.

In addition to crop production, the region is a major livestock producer (beef, mutton, pork, and poultry) and supports a large biofuels industry. Crop, livestock, and biofuel production have developed into an integrated system within the region. Large areas not suited for cropping remain in native vegetation or improved forages and are used for grazing. In North and South Dakota, grazing land increases as precipitation decreases but this is not necessarily true in Nebraska and Kansas (Hendrickson et al. 2008b) potentially because of the impact of irrigation. Animals produced in the region and brought in from other regions are finished in confined feeding operations that utilize locally grown grain and forage. A byproduct of grain ethanol production is distiller's grain which is commonly included as part of the feed ration in confined feeding operations and as a diet supplement for energy, fat, and protein for cows and developing yearlings (stocker steers and replacement heifers). This integrated crop-livestock - biofuel system can provide significant flexibility for producers. The objectives of this paper are to describe anticipated impacts of projected climatic changes in precipitation and temperature during the remainder of the twenty-first century on crop production systems in the Northern Great Plains and provide adaptation strategies that should be developed to take advantage of positive and mitigate negative changes.

\section{Northern Great Plains climate change projections}

\subsection{Temperature}

Projected changes in average annual temperature by the end of the century are an increase of $5.6{ }^{\circ} \mathrm{C}$ in the southern part of the region and $6.7^{\circ} \mathrm{C}$ in the northern part of the region (Pierce et al. 2014, 2015). Projected warming will be greater during winter and spring than during summer and fall and there will be greater warming for nighttime lows than for daytime highs. Evidence for these changes is already emerging. Long-term weather records show an increase in the frost free period of 7 to 10 days when comparing temperatures in 1991-2012 to those from 1901 to 1960. The frost free period is projected to increase by 30 to 40 days by the end of the century. Projections include an increase of 22 to 25 high temperature stress days (daytime temperatures $>37^{\circ} \mathrm{C}$ ) and 25 to 40 warm nights (nighttime temperatures $>15^{\circ} \mathrm{C}$ ) which will have significant impacts on crop and animal production.

\subsection{Precipitation}

Average annual precipitation is projected to increase in the northern part of the region with little or no change in the southern part of the region (Pierce et al. 2014, 2015). Precipitation intensity is also expected to change with an increase in the number of heavy rainfall events. Precipitation received during heavy rainfall often exceeds the infiltration rate of the soil and this precipitation can be lost as runoff. An increase in runoff raises the potential for soil erosion 
(Zhang et al. 2012) and flooding of receiving rivers and streams. Another consequence of heavy rainfall events is precipitation lost due to runoff is not available for crop production (SWCS 2003). Precipitation received during heavy rainfall events from 1991 to 2012 increased 16\% when compared to 1901-1960 (Walsh et al. 2014). Observed trends in amount and intensity of precipitation are projected to become more pronounced.

\section{Cropping system opportunities and vulnerabilities}

\subsection{Soils}

In the southern portion of the region where temperatures are projected to increase with little change in precipitation, it is expected that soil moisture will decrease by 5 to $10 \%$ resulting in an increase in crop water stress. These changes will place additional stress on water resources where irrigation is practiced. In the northern portions of the region where temperature and precipitation are projected to increase, soil moisture will increase. An increase in soil moisture will increase $\mathrm{N}_{2} \mathrm{O}$ emissions (Doran et al. 1990). A longer frost free period and warmer soil temperatures will increase biological activity affecting nutrient cycling and carbon sequestration. Under current management practices, decomposition and mineralization rates will increase resulting in increased nutrient availability and reduced potential for $\mathrm{C}$ sequestration (Cheng et al. 2011; Wienhold et al. 2015). Increases in the amount of precipitation received during high intensity events will increase the potential for leaching and erosion losses of nutrients. Leaching of solutes, lateral flow, and seepage can result in development of saline seeps (Halvorson and Black 1974). Increases in precipitation are resulting in an increase in salinity issues in the northern portion of the region (Lobell et al. 2009). Increased precipitation is also resulting in an increase in installation of tile drainage in eastern North and South Dakota to remove excess soil water to facilitate field operations such as planting in the spring (North Dakota State Water Commission 2015).

\subsection{Water resources}

Warmer winters will result in a greater percentage of precipitation falling as rain instead of snow (Bathke et al. 2014). A major implication is reduced snowpack in mountainous areas that supply runoff for streamflow in rivers that run through the Northern Great Plains. Meeting competing demands for water (recreation, wildlife, municipal, and industrial) in these river systems will likely result in reduced water availability for irrigation of crops. Reduced surface water availability will increase pressure on ground water resources (Burbach et al. 2014). Currently, irrigation for growing crops uses $95 \%$ of the water extracted from the High Plains Aquifer. In Nebraska this portion of the aquifer is closely monitored and managed by Natural Resource Districts and water levels have been maintained (Schneider 2014). The region also benefits from the extensive Sandhills region of north-central Nebraska that serves as a major recharge zone for the aquifer. However, the aquifer in the southwest corner of Nebraska extending into Kansas has seen significant depletion and current extraction rates are not sustainable (Burbach et al. 2014). Increased precipitation in northern part of the region will present opportunities for increased crop production and a geographic shift in the growing of crops with higher water demands. The increase in precipitation is projected to occur during winter and spring with little change during summer and fall. These projected changes may 
create challenges for field operations such as planting, fertilizing and pest control. The northern part of this region has a relatively short growing season and delays in field work may result in some cropland not being planted in some years. Also, much of the northern part of the region has a relatively young landscape with closed topography. An increase in precipitation will result in increasing salinity and waterlogging in some areas. High intensity precipitation will increase the potential for localized flooding.

\subsection{Crop responses}

Crop responses to projected climatic changes will depend on individual crop response to direct effects (higher temperatures, altered precipitation patterns and greater frequency of extreme events, and increasing atmospheric $\mathrm{CO}_{2}$ concentration) and indirect effects (greater abundance and occurrence of agronomic weeds, invasive weeds, insect pests, and pathogens).

All crops have a relatively narrow range in temperature for optimum reproductive (grain) production. Crops are most susceptible to temperature effects during pollination and grain fill. The projected increase in maximum daily temperature will increase the potential for suboptimum pollination and projected increase in extreme temperature days and nights will reduce grain fill. It has been estimated that each $1{ }^{\circ} \mathrm{C}$ increase in average growing season temperature will decrease corn yield by $8.3 \%$ and soybean yield by $13 \%$ (Lobell and Field 2007). Wheat yields are reduced when the crop experiences air temperatures $>31{ }^{\circ} \mathrm{C}$ which reduces pollen and ovule formation leading to fewer and smaller kernels (Ferris et al. 1998).

Reduced water availability will limit crop production. However, Zipper et al. (2016) suggests drought will have less impact on corn and soybean in the Northern Great Plains than in the Southeastern United States. Soil water availability in the southern part of this region is projected to decline and sustaining crop production will require prudent use of available water resources for irrigation (Bathke et al. 2014). Increasing precipitation in the northern part of the region may result in adequate soil water availability benefiting crop production especially in the western part of the region where wheat, dry edible beans, and corn are currently grown under water stress conditions. Precipitation projections are not as certain as temperature projections and the actual crop response will depend on year-to-year variation, the distribution of precipitation received during the growing season, and the amount of precipitation received in extreme events (Shafer et al. 2014).

Crop response to increasing atmospheric $\mathrm{CO}_{2}$ concentration differs between $\mathrm{C}_{3}$ and $\mathrm{C}_{4}$ plants. In general, $\mathrm{C}_{4}$ plants such as corn and sorghum do not exhibit an increase in yield in a higher $\mathrm{CO}_{2}$ environment. Soybean and wheat, which are $\mathrm{C}_{3}$ plants, do exhibit an increase in photosynthesis and a decrease in respiration as atmospheric $\mathrm{CO}_{2}$ concentration increases (Bernacchi et al. 2006). Grain production for $\mathrm{C}_{3}$ crops under higher atmospheric $\mathrm{CO}_{2}$ may result in higher yields but lower quality (protein content) for human and animal nutrition (Erbs et al. 2010; Asif et al. 2016).

Agronomic weeds compete with crops for space, water, and nutrients. Many agronomic weeds have their origin in warmer regions (tropical or warm temperate) and are expected to expand northward with projected increases in air temperature (Patterson et al. 1999; Rahman and Wardle 1990). Invasive weeds are anticipated to be a greater challenge in grasslands than in crop productions areas, however.

Increasing temperatures will impact insect populations in a number of ways. Higher annual temperatures will accelerate insect life cycles and allow expansion of their geographic range (Walther 2010). There is evidence of this already occurring as corn pests are being observed 
farther north as corn production increases in North and South Dakota (Diffenbaugh et al. 2008). Species that are capable of producing multiple generations per year will not only be capable of producing more individuals each growing season but the presence of multiple generations each growing season increases the potential for development of resistance to control measures (e.g., insecticide resistance) (May and Dobson 1986).

The impact of pathogens on crop production under a changing climate is difficult to generalize because of the complexity of the interactions among host-pathogen-vectorenvironment (Coakley et al. 1999). Conditions that reduce the impact of one pathogen may greatly increase the impact of another or result in a pathogen having an impact in a region where it had not been present.

Managing pests and disease under a changing climate will be further challenged by biological, social, and economic factors that influence what practices are available (CAST 2017). Pesticide resistance will reduce the number of products available to manage pests and will modify how practices are implemented to reduce the chance of additional pests from developing resistance. Public perception of pesticides and the cost of developing new products and bringing them to market have slowed the introduction of new pesticides. Integrated pest management with practices deployed area-wide to manage pests will become more common. Advances in identifying new modes of action, biological control agents, seed treatments, and emerging genetic tools will provide new opportunities for pest management as well (CAST 2017).

\section{Adaptation strategies}

Vulnerability of agroecosystems in the Northern Great Plains is dependent on the magnitude and rate of change in weather parameters impacting production and the sustainable provision of other ecosystem services which have neutral to positive environmental impacts. Producer management responses to climatic change include mitigation (e.g., $\mathrm{C}$ sequestration and reducing greenhouse gas emissions) and adaptation strategies (e.g., land use changes and regional water management) (Bathke et al. 2014). In addition to the production of food, feed, fiber, and fuel, these agroecosystems provide additional ecosystem services desired by society such as pollinator services, hydrological and nutrient cycling, and habitat for organisms maintaining regional biodiversity (Power 2010). Currently, the impact is difficult to assess but adaptation strategies should address sustaining the multiple functionality of these systems (Hatfield 2006).

\subsection{Cropping systems}

Projected changes in temperature and precipitation suggest that opportunity exists for further intensification of cropping systems in this region. Increasing precipitation in the northern part of the region should result in reduced use of fallow and provide opportunities for use of cover crops. If there is sufficient soil moisture to support a cover crop without reducing yield of the subsequently planted cash crop a number of benefits result (Basche et al. 2016). The hydrologic cycle may be favorably altered by cover crops to reduce leaching and runoff nutrient losses. Cover crop water use may result in spring soil water conditions more conducive for field operations such as planting and fertilizing. Incorporating cover crops into row crop production can improve soil quality (Moore et al. 2014). Cover crop biomass protects 
soil from wind and water erosion and serves as a substrate to sustain soil biota, thereby increasing the potential for $\mathrm{C}$ sequestration. Cover crops can improve water infiltration by providing root channels and breaking up tillage pans (Kaspar and Singer 2011). Legume cover crops are a source of fixed $\mathrm{N}$ that subsequent crops can utilize which reduces the need for fertilizer $\mathrm{N}$ and improves the energy balance of the production system (Rathje et al. 2007). Non-legume cover crops utilize inorganic $\mathrm{N}$ remaining after harvest reducing the potential for leaching losses and $\mathrm{N}_{2} \mathrm{O}$ emissions. Cover crop production can also play a role in management of agronomic weeds through shading and competition. Cover crops are not a panacea management strategy in all parts of the region as soil water use by cover crops can negatively impact yields of subsequently planted crops in drier (more xeric) portions of this region (Vigil and Nielsen 1997; Nielsen et al. 2015). In other systems, choice of cover crops is important as some may serve as a host for pathogens of subsequent crops (Bakker et al. 2016). Management of the cover crops is crucial to their benefits to provision of both ecosystem goods and services.

Projected changes in temperature and precipitation will change the distribution of crops grown in the region due to the longer growing season and earlier frost free period. There has already been an increase in the amount of corn and soybean produced in the northeastern portion of the region and this trend will likely increase. A recent analysis has concluded that the increase in corn and soybean is the result of replacing perennial grass and increased use of marginal land for row crop production (Wright and Wimberly 2013). These shifts in land use increase the potential for soil erosion, reduce habitat for grassland wildlife, and will constrain efforts to increase use of cellulosic feedstocks for biofuel production. To sustain multiple ecosystem services and break weed, insect pest, and disease cycles there is a need for rotations more diverse than a prevalent cornsoybean rotation or continuous corn. In general, crop diversity in the USA has declined over the past three decades as has occurred in eastern Nebraska, and eastern Dakotas (Aguilar et al. 2015). However, there are other geographic areas in this region where crop diversity has increased, such as central North Dakota which may have been a response to improvements in technology, such as no-till and disease pressure. As cropping patterns change, the migration of weeds, diseases, and insect pests that are not currently present in the region will present management challenges to producers.

\subsection{Improvements in management and genetics}

Numerous studies have shown that past increases in crop production can be equally attributed to improvements in management and genetics (Cassman 1999; Unger and Baumhardt 1999). Efforts to develop crop varieties with increased heat tolerance, drought resistance, and disease resistance are underway. Work is underway in livestock breeding to develop genetics that can reduce the impact of heat stress on fertility and develop heat resistance (Hayes et al. 2013). Cultivars and varieties with these improved traits will have to be utilized appropriately on landscapes by producers. Topography, spatial variation in soil properties, redistribution of water following precipitation or irrigation, aspect influences on plant exposure to wind and solar radiation interact to create significant within-field variation in edaphic conditions and microclimate that effect crop yields (Kaspar et al. 2003). Precision agriculture is a strategy to optimize within-field management (McBratney et al. 2005). Sensors to measure and monitor within field variation need to be developed and interpretation tools and services will have to be provided to improve within-field management. Implements for spatially varying inputs 
(cultivars or crops, fertilizer, irrigation, seeding rates) need continued development. A recent analysis reported that precision agriculture was used on 30 to $50 \%$ of corn and soybean and the impact on producer profits was positive but small (Schimmelpfennig 2016). Improved management will contribute to optimizing crop yields without diminishing other ecosystem services (e.g., water and air quality). For example, within-season fertilizer application to meet crop needs can result in a reduction in the amount of fertilizer applied (Kitchen et al. 2010) which reduces the potential for greenhouse gas emission or contamination of surface or ground water.

\subsection{Integration of crops/livestock (grazing of cover crops and residues)}

Diversity is one of the key elements in providing resilience in ecosystems (Elmqvist et al. 2003) and diversification is a key principle in integrated livestock-crop systems (Hendrickson et al. 2008a). However, agricultural specialization over the past several decades has decoupled crop and cattle production (Sulc and Franzluebbers 2014) and specialized crop producers have shown little interest in adopting integrated production systems for numerous reasons. The agricultural landscape in the Northern Great Plains is unique because it is often a mixture of annual crops, rangeland, and seeded pasture and hayland. This landscape diversity provides opportunities for the spatial and temporal integration of crops and livestock to occur by using rotations of grain crops and perennial pastures, short rotations of grain crops with annual or short-term pastures, and utilization of grain crop residues for livestock grazing (Sulc and Tracy 2007; Sulc and Franzluebbers 2014).

\subsection{Use of perennials}

Changing land use from annual crops to perennial or increasing the number of forage crops in the rotation are strategies for achieving multiple production and conservation goals (Nielsen et al. 2016). As with cover crops, perennial vegetation can alter hydrologic and nutrient cycles to make more efficient use of and reduce contamination of water resources and improve soil quality (Culman et al. 2013). Progress in developing perennial grain crops is emerging (Lubofsky 2016). Development of multiple perennial crops that could be grown in mixtures and equipment for efficiently harvesting mixtures would have a positive effect on management through reduced field work, improved water and nutrient use, multiple marketable crops, and increased system diversity. Perennial vegetation can provide a source of feed for livestock, feedstock for biofuels, and habitat to support regional biodiversity. In addition, because perennials do not need to be reseeded annually and have extensive root systems, they can provide a source of system resilience in changing climatic conditions.

\subsection{Grazing of cover crops and residues}

Integration of livestock and cropping enterprises can provide for greater local or farmlevel flexibility to adapt to weather variability and changing climate (Lemaire et al. 2014). Integrating livestock with annual cropping systems can provide a biological insurance for producers for years when climate variability may adversely impact annual crop production. Residues from either failed annual crops or crop residue from average years can be utilized by livestock (Schiere et al. 2002). Projected increases in spring 
precipitation may result in some cropland not being planted to annual crops. The use of cover crops as forage would still allow production from these areas.

Integrated crop-livestock systems can also benefit livestock production. For example, Kentucky bluegrass (Poa pratensis L.) which has become a common component of grassland vegetation in North and South Dakota is negatively impacted by heat and drought (Liu et al. 2008) thereby reducing the resilience of grazing lands during times of moisture and heat stress and shifting the forage cycle to early spring. Integrated crop-livestock systems can adapt to this weather-mediated plant invasion by utilizing cover crops or crop residue to fill the late season forage cycle. However, these integrated crop-livestock systems may require a higher management input (Hendrickson et al. 2008a).

\subsection{Socio-economic considerations}

As impacts of projected climatic changes in the Northern Great Plains continue to emerge and strategies for adaptation are planned and developed, socio-ecological-economic and cultural/ institutional changes to support them will have to be included. Land use changes and allocation of water resources among competing uses will have to acknowledge societal demands and need to sustain the multiple functions and ecosystem services provided. Mechanisms for sustaining the economic viability of production systems under more variable conditions are needed. The insurance industry is one of the largest businesses in the world and will be impacted greatly by a more variable and changing climate as customers look to them to recover from losses in production, property, and infrastructure (Liska and Holley 2014). Government loan, price support, and insurance programs will also be needed to overcome year-to-year fluctuations experienced by producers. Public and industry research, and development of extension/education programs will be key to wise implementation of changing management practices. There are a number of innovative producers and many are early adapters of emerging technology but their lessons will need to be translated to other producers through field-days and demonstration projects.

\section{References}

Aguilar J, Gramig GG, Hendrickson JR, Archer DW, Forcella F, Liebig MA (2015) Crop species diversity changes in the United States: 1978-2012. PLoS One 10(8):0136580

Asif J, Yilmaz O, Ozturk O (2016) Elevated carbon dioxide ameliorates the effect of Zn deficiency and terminal drought on wheat grain yield by nutritional quality. Plant Soil. doi:10.1007/s11104-016-2996-9

Bakker MG, Moorman TB, Kaspar TC, Manter DK (2016) Winter rye cover crops as a host for corn seedling pathogens. Am Phytopatho Soc 106:S1.2. doi:10.1094/PHYTO-106-1-s1.1

Basche AD, Archontoulis S, Kaspar TC, Jaynes DB, Parkin TB, Miguez F (2016) Simulating long-term impacts of cover crops and climate change on crop production and environmental outcomes in the midwestern United States. Agric Ecosystems Environ 218:95-106. doi:10.1016/j.agee.2015.11.011

Bathke DJ, Oglesby RJ, Rowe CM, Whilhite DA (2014) Understanding and assessing climate change: implications for Nebraska. A synthesis report to support decision making and natural resource management in a changing climate. School of Natural Resources, Institute of Agriculture and Natural Resources. University of Nebraska - Lincoln, Lincoln, p 73

Bernacchi CJ, ADB L, Heady LE, Morgan PB, Dohleman FG, JM MG, Gillespie KM, Wittig VE, Rogers A, Long SP, Ort DR (2006) Hourly and seasonal variation in photosynthesis and stomatal conductance of soybean grown at future $\mathrm{CO}_{2}$ and ozone concentrations for 3 years under fully open-air field conditions. Plant Cell Environ 29(11):2077-2090

Burbach ME, Young AR, Korus JT (2014) The potential impacts of projected changes in climate on groundwater resources in Nebraska. In: Bathke DJ, Oglesby RJ, Rowe CM, Wilhite DA (eds) Understanding and 
assessing climate change: implications for Nebraska. A synthesis report to support decision making and natural resource management in a changing climate. School of Natural Resources, Institute of Agriculture and Natural Resources. University of Nebraska - Lincoln, Lincoln, p 40

Cassman KG (1999) Ecological intensification of cereal production systems. Yield potential, soil quality, and precision agriculture. Proc Nat Acad Sci USA 96:5952-5959

Cheng L, Booker FL, Burkey KO, Tu C, Shew HD, Rufty TW, Fiscus EL, Deforest JL, Hu S (2011) Soil microbial responses to elevated $\mathrm{CO}_{2}$ and $\mathrm{O} 3$ in a nitrogen-aggrading agroecosystem. PLoS One 6(6):e21377

Coakley SM, Sherm H, Chakraborty S (1999) Climate change and plant disease management. Annu Rev Phytopathol 37:399-426

Council for Agricultural Science and Technology (CAST) (2017) Crop production contributions toward agricultural productivity: the need for agricultural innovation to sustainably feed the world by 2050. Issue Paper 58. CAST, Ames

Culman SW, Snapp SS, Ollenburger M, Basso B, LR DH (2013) Soil and water quality rapidly responds to perennial grain Kernza wheatgrass. Agron J 105:735-744

Diffenbaugh NS, Krupke CH, White MA, Alexander CE (2008) Global warming presents new challenges for maize pest management. Environ Res Letters 4:044007

Doran JW, Mielke LN, Power JF (1990) Microbial activity as regulated by soil water-filled pore space. In: Transactions of the 14th International Congress of Soil Science, Kyoto, Japan. International Soil Science Society, Wageningen, pp 94-100

Elmqvist T, Folke C, Nyström M, Peterson G, Bengtsson J, Walker B, Norberg J (2003) Response diversity, ecosystem change, and resilience. Front Ecol Environ 1:488-494

Erbs M, Manderscheid R, Jansen G, Seddig S, Pacholski A, Weigel H-J (2010) Effects of free-air $\mathrm{CO}_{2}$ enrichment and nitrogen supply on grain quality parameters and elemental composition of wheat and barley grown in crop rotation. Agric Ecosyst Environ 136:59-68

Ferris R, Ellis RH, Wheeler TR, Hadley P (1998) Effect of high temperature stress at anthesis on grain yield and biomass of field-grown crops of wheat. Ann Bot 82(5):631-639

Halvorson AD, Black AL (1974) Saline seep development in dryland soils of north-eastern Montana. J Soil Water Conserv 29:77-81

Hatfield JL (2006) Multifunctionality of agriculture and farming system design: perspectives from the United States. Bibliotecha Fragmenta Agronomica 11:43-52

Hayes BJ, Lewin HA, Goddard ME (2013) The future of livestock breeding: genomic selection for efficiency, reduced emissions intensity, and adaptation. Trends Genet 29:206-214

Hendrickson JR, Hanson JD, Tanaka DL, Sassenrath G (2008a) Principles of integrated agricultural systems: introduction to processes and definition. Renew Agric Food Syst 23(04):265-271

Hendrickson JR, Liebig MA, Sassenrath GF (2008b) Environment and integrated agricultural systems. Renew Agric Food Syst 23:304-313

Kaspar TC, Singer JW (2011) The use of cover crops to manage soil. In: Hatfield JL, Sauer TJ (eds) Soil management: building a Stable Base for agriculture. American Society of Agronomy and Soil Science Society of America, Madison, pp 321-337

Kasper TC, Colvin TS, Jaynes B, Karlen DL, James DE, Meek DW (2003) Relationship between six years of corn yields and terrain attributes. Precis Agric 4:87-101

Kitchen NR, Sudduth KA, Drummond ST, Scharf PC, Palm HL, Robert DF, Vories ED (2010) Ground-based canopy reflectance sensing for variable-rate nitrogen corn fertilization. Agron J 102:71-84

Lauenroth WK, Burke IC, Gutmann MP (1999) The structure and function of ecosystems in the central north American grassland region. Great Plains Res 9:223-259

Lemaire G, Franzluebbers A, de Faccio Carvalho PC, Dedieu B (2014) Integrated crop-livestock systems: strategies to achieve synergy between agricultural production and environmental quality. Agric Ecosyst Environ 190:4-8

Liska A, Holley E (2014) Climate change and its implications for the insurance industry. In: Bathke DJ, Oglesby RJ, Rowe CM et al (eds) Understanding and assessing climate change: implications for Nebraska. A synthesis report to support decision making and natural resource management in a changing climate. School of Natural Resources, Institute of Agriculture and Natural Resources. University of Nebraska Lincoln, Lincoln, pp 59-60

Liu J, Xie X, Du J, Sun J, Bai X (2008) Effects of simultaneous drought and heat stress on Kentucky bluegrass. Sci Hortic 115(2):190-195

Lobell DB, Field CB (2007) Global scale climate-crop yield relationships and the impacts of recent warming. Environ Res Lett 2(1):014002

Lobell DB, Lesch SM, Corwin DL, Ulmer MG, Anderson KA, Potts DJ, Doolittle JA, Baltes MJ (2009) Regional-scale assessment of soil salinity in the Red River Valley using multi-year MODIS EVI and NDVI. J Environ Qual 39:35-41 
Lubofsky E (2016) The promise of perennials. CSA News, November 2016 pp 4-7

May RM, Dobson AP (1986) Population dynamics and the rate of evolution of pesticide resistance, in pesticide resistance: strategies and tactics for management. National Research Council Committee on Strategies for the Management of Pesticide Resistant Pest Populations, National Academy Press, Washington, D.C

McBratney A, Whelan B, Ancev T (2005) Future directions of precision agriculture. Precis Agric 6:7-23

Moore EB, Kaspar TC, Wiedenhoeft MH, Cambardella CA (2014) Rye cover crop effects on soil quality in notill silage-soybean cropping systems. Soil Sci Soc Am J 78:968-976

Nielsen DC, Lyon DJ, Higgens RK, Hergert GW, Holman JD, Vigil MF (2015) Cover crop effect on subsequent wheat yield in the central Great Plains. Agron J 108:243-256

Nielsen DC, Vigil MF, Hansen NC (2016) Evaluating potential dryland cropping systems adapted to climate change in the central Great Plains. Agron J 108:2391-2405

North Dakota State Water Commission (2015) Trends in North Dakota field water management. The Oxbow, April 2015, pp 16-18

Patterson DT, Westbrook JK, Joyce RJV, Lingren PD, Rogasik J (1999) Weeds, insects, and diseases. Clim Chang 43(4):711-727

Pierce DW, Cayan DR, Thrasher BL (2014) Statistical downscaling using localized constructed analogs (LOCA). J Hydrometeorol 15:2558-2585

Pierce DW, Cayan DR, Maurer EP, Abatzoglou JT, Hegewisch KC (2015) Improved bias correction techniques for hydrological simulations of climate change. J Hydrometeorol 16:2421-2442

Power AG (2010) Ecosystem services and agriculture: tradeoffs and synergies. Philos Trans the R Soc B Biol Sci 365(1554):2959-2971

Rahman A, Wardle D (1990) Effects of climate change on cropping weeds in New Zealand. In: Prestidge RA, Pottinger RP (eds) The impact of climate change on pests, diseases, weeds and beneficial organisms present in New Zealand agricultural and horticultural systems. Ruakura Agricultural Centre, Hamilton, pp 107-112

Rathje G-W, Wienhold BJ, Wilhelm WW, Diepenbrock W (2007) Tillage and rotation effect on corn-soybean energy balances in eastern Nebraska. Soil Tillage Res 97:60-70

Schiere JB, Ibrahim MNM, Van Keulen H (2002) The role of livestock for sustainability in mixed farming: criteria and scenario studies under varying resource allocation. Agric Ecosyst Environ 90(2):139-153

Schimmelpfennig D (2016) Farm profits and adoption of precision agriculture. ERR-217, US Department of Agriculture, Economic Research Service, October 2016

Schneider JC (2014) Implications of a changing climate for Nebraska's water resources and its management. In: Bathke DJ, Oglesby RJ, Wilhite DA (eds) Understanding and assessing climate change: implications for Nebraska. A synthesis report to support decision making and natural resource management in a changing climate. School of Natural Resources, Institute of Agriculture and Natural Resources. University of Nebraska - Lincoln, Lincoln, p 42

Shafer M, Ojima D, Antle JM, Kluck D, McPherson RA, Petersen S, Scanlon B, Sherman K (2014) Ch. 19: Great Plains. Climate Change Impacts in the United States: The Third National Climate Assessment. In: Melillo JM, Richmond TTC, Yohe GW (eds) U.S. Global Change Research Program, pp 441-461, Doi:10.7930/JOD798BC

Soil and Water Conservation Society (2003) Soil erosion and runoff from cropland report from the USA. Soil and Water Conservation Society, Ankeny, p 63

Springer G, Wienhold BJ, Richardson JL, Disrud LA (1999) Salinity and sodicity induced changes in dispersible clay and saturated hydraulic conductivity is sulfatic soils. Commun Soil Sci Plant Anal 30:2211-2220

Sulc RM, Franzluebbers AJ (2014) Exploring integrated crop-livestock systems in different ecoregions of the United States. Eur J Agron 57:21-30

Sulc RM, Tracy BF (2007) Integrated crop-livestock systems in the US Corn Belt. Agron J 99(2):335-345

Unger PW, Baumhardt RL (1999) Factors related to dryland grain sorghum yield increases: 1939 through 1997. Agron J 91:870-875

USDA-NASS (2013) Farm and ranch irrigation survey. 2012 Census of Agriculture. National Agricultural Statistics Service. US Department of Agriculture

USDA-NASS (2016a) Crop Production 2015 Summary. U.S. Department of Agriculture, National Agricultural Statistic Service, Washington, DC

USDA-NASS (2016b) Crop Values 2015 Summary. U.S. Department of Agriculture, National Agricultural Statistic Service, Washington, DC

Vigil MF, Nielsen DC (1997) Winter wheat yield depression from legume green fallow. Agron J 90: $727-734$

Walsh J, Wuebbles K, Hayhoe K, Kossin J, Kunkel K, Stephens G, Thorne P, et al., (2014) Ch. 2: our changing climate. Climate change impacts in the United States: the third national climate assessment. In: Melillo JM, Richmond TTC, Yohe GW (eds) U.S. Global Change Research Program, pp 19-67. doi:10.7930/J0KW5CXT 
Walther G-R (2010) Community and ecosystem responses to recent climate change. Philos Trans R Soc B Biol Sci 365(1549):2019-2024

Wienhold BJ, Schmer MR, Jin VL, Varvel GE, Gollany H (2015) CQESTR simulated changes in soil organic carbon under residue removal practices in continuous corn systems. Bioenergy Res 9:23-30

Wright CK, Wimberly MC (2013) Recent land use change in the Western Corn Belt threatens grassland and wetlands. Proc Natl Acad Sci 110:4134-4139

Zhang Y-G, Hernandez M, Anson E, Nearing MA, Wei H, Stone JJ, Heilman P (2012) Modeling climate change effects on runoff and soil erosion in southeastern Arizona rangelands and implications for mitigation with rangeland conservation practices. J Soil Water Conserv 67(5):390-405

Zipper SC, Qiu J, Kucharik CJ (2016) Drought effects on US maize and soybean production: spatiotemporal patterns and historical changes. Environ Res Lett 11(9):094021 